\title{
DETERMINING THE TECHNOLOGICAL PARAMETERS OF OBTAINING EXTRACTION OF SUMAC FOR FURTHER USE IN THE TECHNOLOGY OF SOUR-MILK PASTE
}

\author{
N. Yushchenko, T. Grabova, U. Kuzmyk, V. Pasichnyi \\ National University of Food Technologies
}

\begin{tabular}{|c|c|}
\hline Key words: & ABSTRACT \\
\hline $\begin{array}{l}\text { Aromatic raw materials } \\
\text { Sumac } \\
\text { Whey } \\
\text { Phenolic compounds } \\
\text { Extraction } \\
\text { Fermented pastes }\end{array}$ & $\begin{array}{l}\text { The article substantiates the feasibility of using sumac } \\
\text { (Rhus L.) fermented pastes in sour-milk technology as a } \\
\text { source of biologically active compounds and for forming the } \\
\text { organoleptic properties of ready products. The method and } \\
\text { technological parameters of using sumac fruits are determi- } \\
\text { ned. It is found that sumac should be applied as an extract }\end{array}$ \\
\hline $\begin{array}{l}\quad \text { Article history: } \\
\text { Received } 15.05 .2017 \\
\text { Received in revised form } \\
02.06 .2017 \\
\text { Accepted } 22.06 .2017\end{array}$ & $\begin{array}{l}\text { based on the milk whey. The efficiency of making the extract } \\
\text { using a rotary impulse extractor has been proved. The rational } \\
\text { modes of extraction have been determined for the efficiency } \\
\text { of extraction of phenolic compounds with P-vitamin activity } \\
\text { (total content on halic acid, routine, catechin) and tannin: the }\end{array}$ \\
\hline $\begin{array}{l}\text { Corresponding author: } \\
\text { N. Yushchenko } \\
\text { E-mail: } \\
\text { npnuht@ukr.net }\end{array}$ & $\begin{array}{l}\text { temperature of } 80 \ldots 85^{\circ} \mathrm{C} \text {; duration of the process }-10 \mathrm{mi}- \\
\text { nutes. The content of phenolic compounds in the extract was } \\
107.8 \mathrm{mg} / 100 \mathrm{~g} \text {; the content of routine was } 3.4 \mathrm{mg} / 100 \mathrm{~g} \text {; } \\
\text { catechin }-1.9 \mathrm{mg} / 100 \mathrm{~g} \text {; tannin }-1.4 \mathrm{mg} / 100 \mathrm{~g} \text {, which } \\
\text { would provide the daily need for routine by } 5.7 \% \text {, catechin } \\
\text { by } 1.9 \% \text {, and tannin by } 0.7 \% \text {, respectively. }\end{array}$ \\
\hline
\end{tabular}

DOI: $10.24263 / 2225-2924-2017-23-4-23$

\section{ВИЗНАЧЕННЯ ТЕХНОЛОГІЧНИХ ПАРАМЕТРІВ ОТРИМАННЯ ЕКСТРАКТУ СУМАХУ ДЛЯ ПОДАЛЬШОГО ВИКОРИСТАННЯ У ТЕХНОЛОГІЇ КИСЛОМОЛОЧНИХ ПACT}

\author{
Н.М. Ющенко, Т.Л. Грабова, У.Г. Кузьмик, В.М. Пасічний \\ Національний університет харчових технологій
}

У статті обтрунтовано доцільність використання плодів сумаху (Rhus L.) у технології кисломолочних паст як джерела біологічно активних сполук та з метою формування органолептичних властивостей готових продуктів. Визначено спосіб і технологічні параметри введення плодів сумаху. Встановлено, щзо сумах доцільно вводити у вигляді екстракту на основі молочної сироватки. Доведено ефективність виготовлення екстракту із використанням роторно-імпульсного екстрактору. Визначено раціональні режими екстрагування за ефективністю вилучення фенольних сполук с Р-вітаміною активністю (загальний вміст по галовій кислоті, по рутину, катехіну), таніну — 
температура $80 \ldots 85^{\circ}$ C, тривалість проиесу 310 хвилин. Вміст фенольних сполук у екстракті становив - 107,8 мг/100 2, вміст рутину - 3,4 мг/100 2, катехіну - 1,9 мг/100 г, таніну - 1,4 мг/100 г, щңо дозволить забезпечити добову потребу відповідно у рутині - на 5,7\%, катехіни - на 1,9\%, таніні на $0,7 \%$.

Ключові слова: пряно-ароматична сировина, сумах, фенольні сполуки, екстрагування, кисломолочні пасти.

Постановка проблеми. Розроблення нових видів кисломолочних продуктів 3 використанням природних інгредієнтів, що збагачують продукт біологічно активними речовинами, є актуальним. 3 цією метою використовують різноманітні добавки та наповнювачі: харчові волокна, сухі фрукти, овочі та прянощі. Прянощі відомі широкою гамою смако-ароматичних властивостей, $\epsilon$ джерелом біологічно активних сполук, серед яких фенольні сполуки, до складу яких входять рутин, катехіни, антоціани, флавонони, флавоноли та ін. $[1 ; 2]$. Приготування екстрактів прянощів дає змогу більш повно вилучити біологічно активні речовини з рослинної сировини та використовувати їх у концентрованому вигляді [3-5].

Аналіз останніх досліджень і публікацій. 3 аналізу досліджень відомо, що фенольні речовини містять велику кількість гідроксильних груп, які дають змогу проявляти антиоксидантні властивості, поглинати атомарний кисень, нейтралізувати вільні радикали та зупиняти ланцюгові реакції [6; 7]. Антиоксидантні властивості фенольних речовин у 4-5 разів переважають антиоксидантний потенціал вітамінів С та $\mathrm{E}$ [8; 9]. Мономерні форми мають найбільшу біологічну активність 3 усіх представників фенольних речовин, основними 3 яких є лейкоантоціани та катехін, що регулюють проникність капілярів і збільшують пружність їх стінок, а також сприяють більш ефективному використанню організмом аскорбінової кислоти. Катехіни та лейкоантоціани також відносять до речовин, що володіють Р-вітамінною активністю, i використовують при лікуванні захворювань, пов'язаних 3 порушеннями функцій капілярів та мають кардіологічну дію [10].

Для створення нових видів молочних продуктів обрали подрібнені плоди пряності сумах (Rhus L.). Сумах містить багато органічних кислот, вітаміну C, наявні яблучна, лимонна, винна, янтарна, малеїнова, фумарова, аскорбінова кислоти. До складу також входять леткі олії, альдегіди, терпеноїди, жирні олії. Вміст ефірної олії до 3\%, головний компонент якої мирцен (до 52\%) [11].

Мета дослідження: вивчення зміни кількісного вмісту біологічно активних речовин в пряності сумах у процесі екстрагування за різних температурних режимів і тривалості процесу.

Матеріали і методи. Дослідження здійснювались у межах держбюджетної науково-дослідної роботи «Наукові засади розроблення ресурсоощадних технологій білоквмісних поліфункціональних концентратів для харчових продуктів цільового призначення» (№ держреєстрації 0117U001243).

Приготування екстракту здійснювалось із використанням роторноімпульсного апарата (PIA). Застосування роторно-імпульсних екстракторів 
дає змогу інтенсифікувати вилучення екстрактивних речовин порівняно 3 традиційними методами, покращити мікробіологічні показники отриманих екстрактів за рахунок герметичності контуру та забезпечити енергоефективність процесу [12].

Сумарний вміст фенольних сполук визначали за допомогою електрофотоколориметрі КФК-2МП при довжині хвилі 640 нм із застосуванням реактиву Фоліна-Чокальтеу, що складається із суміші фосфорно-вольфрамової й фосфорно-молібденової кислот, які відновлюються під час окиснення фенолів до суміші оксидів. При цьому утворюється блакитне забарвлення, інтенсивність якого пропорційнеа кількості фенольних речовин. Кількість фенольних сполук визначалась за допомогою каліброваного графіка, побудованого за стандартними розчинами галової кислоти [13].

Визначення вмісту таніну, рутину та катехіну визначали методом титрування $10 \mathrm{~cm}^{3}$ екстракту $0,1 \mathrm{H}$ розчином $\mathrm{KM}_{\mathrm{n}} \mathrm{O}_{4}$. Завершення процесу титрування встановлювали за появою золотисто-жовтого відтінку розчину. Результат множився на перерахунковий коефіцієнт (для переведення 0,1 н розчину $\mathrm{KM}_{\mathrm{n}} \mathrm{O}_{4}$ в 1 мг фенольних сполук, що містяться в $10 \mathrm{~cm}^{3}$ взятого на титрування екстракту). Коефіцієнт перерахунку становив: для таніну 4,16; рутину $-9,8$; катехіну $-5,5$.

Викладення основних результатів дослідження. На підставі попередніх досліджень розроблені рецептури кисломолочних паст, до складу яких входить екстракт сумаху [14]. Завдяки збалансованому співвідношенню основних харчових компонентів: білків, жирів, вуглеводів, мінеральних речовин, вітамінів кисломолочні пасти володіють дієтичними властивостями. Введення до складу кисломолочної основи натуральної пряно-ароматичної сировини дає змогу не тільки отримати продукти 3 оригінальними органолептичними показниками, а й збагатити комплексом біологічно активних сполук. Перспективним у цьому напрямі $є$ використання плодів сумаху, що надають продуктам пряного аромату із слабкою кислинкою та забезпечують приємне рожево-малинове забарвлення, стійке до технологічного оброблення та під час зберігання готових продуктів. Попередніми дослідженнями визначено доцільність використання сумаху у вигляді екстракту на основі молочної сироватки (гідромодуль - 10). Плоди сумаху попередньо подрібнювались до розміру частинок не більше 2 мм. Метою подальших досліджень було уточнення технологічних параметрів отримання екстракту сумаху із використанням роторно-імпульсного екстрактору.

На першому етапі досліджень температуру процесу змінювали від 20 до $95^{\circ} \mathrm{C}$ з інтервалом у $5^{\circ} \mathrm{C}$, тривалість процесу — до 30 хвилин, вимірювання здійснювали кожні 5 хвилин.

Вплив температури екстрагування й тривалості процесу на ступінь вилучення фенольних сполук наведено у таблиці.

Аналізуючи отримані дані можна зробити висновок, що із збільшенням температури процесу від 20 до $80^{\circ} \mathrm{C}$ ступінь вилучення фенольних сполук зростає, при подальшому підвищенні температури цей процес проходить дещо повільніше. Так, при збільшенні температури від 65 до $80^{\circ} \mathrm{C}$ за тривалості процесу 10 хвилин вміст фенольних сполук підвищується на 7,6 мг/100 г, 
тоді як при збільшенні температури від 80 до $95^{\circ} \mathrm{C}$ за тієї ж тривалості процесу вміст фенольних сполук підвищується всього на 0,7 мг/100 г. При цьому стабілізація показника вмісту фенольних сполук спостерігаються при тривалості процесу від 5 хвилин.

Таблиия Залежність вмісту фенольних сполук в екстракті сумаху від температури екстрагування і тривалості процесу $(n=3, P \geq 0,95)$

\begin{tabular}{|c|c|c|c|c|c|c|c|}
\hline \multirow{2}{*}{ Температура, ${ }^{\circ} \mathrm{C}$} & \multicolumn{7}{|c|}{ Вміст фенольних сполук, мг/100 г } \\
\cline { 2 - 8 } & \multicolumn{7}{|c|}{ Тривалість витримки, хв } \\
\cline { 2 - 8 } & 0 & 5 & 10 & 15 & 20 & 25 & 30 \\
\hline 20 & 75,9 & 78,2 & 79,8 & 80,0 & 81,2 & 82,8 & 83,6 \\
\hline 35 & 85,1 & 88,6 & 90,3 & 90,8 & 91,4 & 92,4 & 92,8 \\
\hline 50 & 94,8 & 95,1 & 95,9 & 96,1 & 96,8 & 97,4 & 97,8 \\
\hline 65 & 98,8 & 99,4 & 100,2 & 100,4 & 100,9 & 101,6 & 101,8 \\
\hline 80 & 106,1 & 107,2 & 107,8 & 108,0 & 108,0 & 108,2 & 108,2 \\
\hline 95 & 108,0 & 108,2 & 108,5 & 108,8 & 108,8 & 109,2 & 109,4 \\
\hline
\end{tabular}

Оскільки підвищення температури негативно впливає на вміст біологічно цінних компонентів, на наступному етапі досліджень більш детально досліджували виділений діапазон температурних режимів екстрагування (від 65 до $95^{\circ} \mathrm{C}$ ) з метою уточнення параметрів, за яких забезпечується ефективне вилучення біологічно активних речовин з плодів сумаху. Тривалість процесу при цьому становила 5 хвилин.

Встановлено, що вміст фенольних сполук в екстракті сумаху (рис. 1) значно зростає при підвищенні температури до $80^{\circ} \mathrm{C}-3$ 100,2 до 107,8 мг/100 г, при подальшому підвищенні температури вміст фенольних сполук у екстракті практично не змінювався.

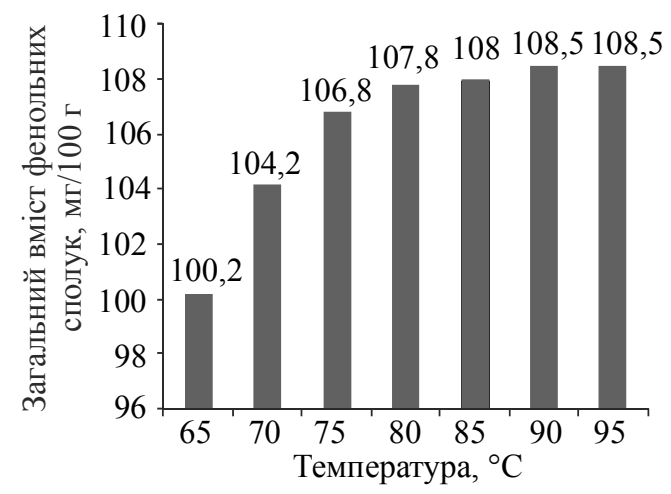

Рис. 1. Вплив температури на вміст фенольних сполук в екстракті сумаху $(n=3, P \geq 0,95)$

Таким чином, для максимального вилучення фенольних сполук процес екстрагування потрібно проводити за температури не нижче $80^{\circ} \mathrm{C}$.

Вміст рутину, катехіну й таніну при підвищені температури також зростає (рис. 2). Так, за температури $65^{\circ} \mathrm{C}$ в екстракті сумаху вміст рутину становить 2,9 мг 100 г, катехіну - 1,6 мг/100 г, таніну - 1,2 мг/100 г, а за температури $95^{\circ} \mathrm{C}$ вміст рутину - 3,6 мг/100 г, катехіну $-2,0$ мг/100 г, таніну - 1,5 мг/100 г. 


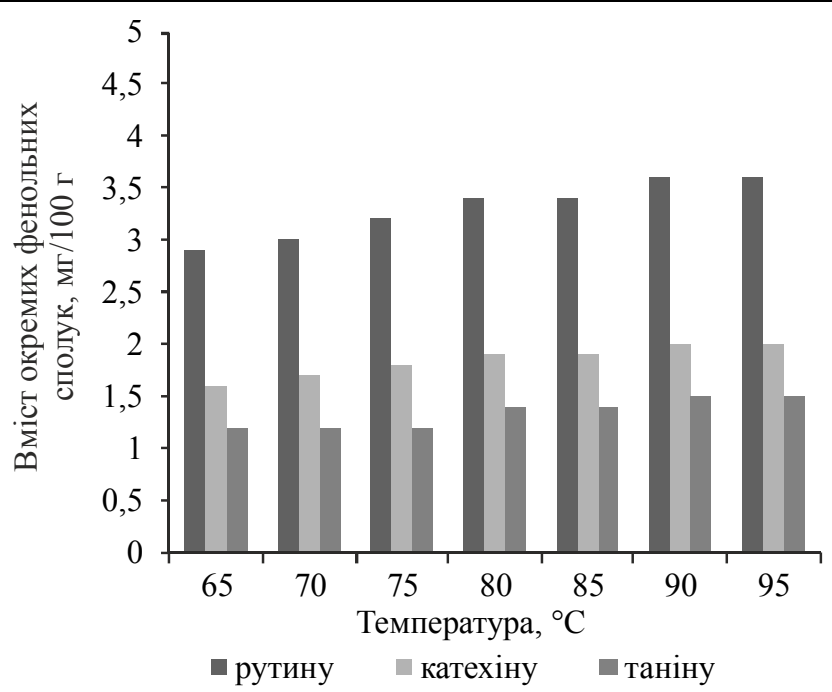

Рис. 2. Вплив температури на вміст рутину, катехіну і таніну в екстракті сумаху

$$
(n=3, P \geq 0,95)
$$

Здійснено розрахунок ступеня забезпечення добової потреби людини в окремих фенольних сполуках з Р-вітамінною активністю при вживанні 100 г кисломолочної пасти (згідно з розробленими рецептурами доза введення екстракту $-10 \%)$. Результати розрахунків наведені на рис. 3. Дані свідчать, що споживання кисломолочних паст з екстрактом сумаху дасть змогу забезпечити добову потребу в рутині на 5,7\%, таніні — на 0,7\%, катехіні — на 1,9\%.

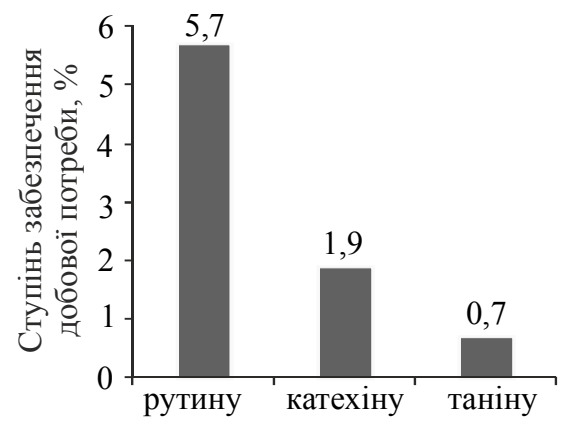

Рис. 3. Ступінь забезпечення добової потреби окремих видів фенольних сполук

\section{Висновки}

На підставі аналізу результатів проведених досліджень визначено раціональні технологічні параметри отримання екстракту сумаху на основі молочної сироватки із використанням роторно-імпульсного екстрактору - температура $80 \ldots 85^{\circ} \mathrm{C}$, тривалість процесу - не менше 5 хвилин, що дає змогу максимально вилучити біологічно активні речовини 3 рослинної сировини та забезпечити енергетичну ефективність процесу. Використання екстракту сумаху у технології кисломолочних паст надає можливість збагатити їх комплексом біологічно активних речовин, зокрема фенольних сполук із Р-віта- 
мінною активністю та сприятиме формуванню оригінальних органолептичних властивостей готових продуктів.

\section{Література}

1. Осипова Л.А. Функциональные напитки на основе пряно-ароматического растительного сырья / Л.А. Осипова, Л.В. Капрельянц // Пищевая промышленность. — 2007. — № 9. - C. 74-75.

2. Павлюк Р.Ю. Розробка технології наноекстрактів та нанопорошків із прянощів для оздоровчих продуктів / Р.Ю. Павлюк, В.В. Погарська, Л.О. Радченко, О.О. Юр'єва, А.Е. Гасанова, Т.С. Абрамова, Т.М. Коломієць // Восточно-Европейский журнал передовых технологий. - 2015. - № 3/10(75). - С. 54-59.

3. Ширшова Т.И. Экстракция как метод выделения биологически активных соединений: краткий обзор / Т. И. Ширшова // Вестник Института биологии Коми НЦ УрО РАН. 2002. 一 № 57. - C. $41-42$.

4. Ukrainets A. Oleoresins effect on cooked poultry sausages microbiological stability / A.I. Ukrainets, V. Pasichniy, Yu. Zheludenko, S. Zadkova // Ukrainian Food Journal. — 2016. Volume 5, Issue 1. - C. 124-134.

5. Pasicniy $V$. The use of polymers as carriers in encapsulation of spice oleoresins / V. Pasicniy, Y. Khomenko, M. Polumbryk // Ukrainian Journal of Food Science. - 2014. Volume 3, Issue 3. - C. 382-387.

6. Faccim de Brum T. HPLC Analysis of Phenolics Compounds and Antioxidant Capacity of Leaves of Vitex megapotamica (Sprengel) Moldenke / T. Faccim de Brum, M. Zadra, M. Piana, S. Terra Stefanello, B. Vargas Belke, L. Teixeira Nunes // Molecules. - 2013. - № 18. P. $8342-8357$.

7. Boligon A.A. Antioxidant activities of flavonol derivates from the leaves and stem bark of Scutia buxifolia Reiss Bioresour / A.A. Pereira, R.P. Feltrin, A.C. Machado, M.M. Janovik // Boligon Technol. — 2009. — № 100. - P. 6592-6598.

8. Ukrainets A. Plant extracts antioxidant properties for meat processing industry / A.I. Ukrainets, V. Pasichniy, Yu. Zheludenko // Biotechnologia Acta. - 2016. - T. 9. — № 2. - C.19-27.

9. Пасічний В.М. Дослідження факторів пролонгації термінів зберігання м'ясних та м'ясомістких продуктів / В.М. Пасічний, А.М. Гередчук, О.О. Мороз, Ю.А. Ястреба // Наукові праці Національного університету харчових технологій. — 2015. — Т. 21. — № 4 (2015). - C. 224-230.

10. Барабой В.А. Катехины чайного растения: структура, активность, применение / В.А. Барабой // Биотехнология. — 2008. — № 3. - С. 25-36.

11. Jixiang Lai Ultrasonic Extraction of Antioxidants from Chinese Sumac (Rhus typhina L.) Fruit Using Response Surface Methodology and Their Characterization / Jixiang Lai, Huifang Wang, Donghui Wang, Fang Fang, Fengzhong Wang // Molecules. - 2014. - № 19. P. 9019-9032.

12. Грабова Т.Л. Метод ДИВЭ в инновационных технологиях и тепломассообменном оборудовании / А.А. Долинский, Л.Н. Грабов, Т.Л. Грабова // Промышленная теплотехника. - 2012. - № 3. - С. 18-30.

13. Фрукти, овочі та продукти їх переробки. Методи визначення вмісту поліфенолів: ДСТУ 4373:2005. - [Чинний від 2005-28-02]. - Київ : Держспоживстандарт України, 2006. $-6 \mathrm{c}$.

14. Kuzmyk U. Structure stabilization of fermented-milk pastes / V. Pasichnyi, N. Yushchenko, I. Mykoliv, U. Kuzmyk // Ukrainian Food Journal. — 2015. — 4. — P. $431-439$. 